\title{
PENGARUH EKSTRAK DAUN BUASBUAS (Premna pubescens Blume) TERHADAP PERTUMBUHAN BAKTERI Staphylococcus aureus SECARA IN VITRO
}

\author{
Gita Widiyastuti dan Martina Restuati \\ Program Studi Biologi, FMIPA, Universitas Negeri Medan \\ trestuati@gmail.com
}

\begin{abstract}
ABSTRAK
Buasbuas (Premna pubescens Blume) merupakan salah satu tumbuhan obat di Indonesia. Tumbuhan ini diketahui mengandung flavonoid yang berpotensi sebagai antibakteri. Staphylococcus aureus merupakan salah satu bakteri yang dapat menyebabkan keracunan. Penelitian ini bertujuan untuk mengetahui apakah ekstrak daun buasbuas dapat menghambat pertumbuhan bakteri Staphylococcus aureus dan untuk mendapatkan data konsentrasi eksrak daun buasbuas yeng menghasilkan zona hambat terbesar. Penelitian ini dilaksanakan di Laboratorium Kesehatan Medan dengan menggunakan metode sumuran. Daun buasbuas yang telah menjadi ekstrak etanol, diencerkan menggunakan aquadest dengan konsentrasi 0\%, 50\%, 60\%, 70\%, 80\%, 90\% dan diteteskan ke dalam media MSA (Mannitol Salt Agar) yang telah diinokulasi bakteri serta diberi lubang sumuran. Setelah itu diinkubasi selama $1 \times 24$ jam dengan suhu $37^{\circ} \mathrm{C}$. Hasil penelitian yang diperoleh menunjukkan bahwa pemberian ekstrak daun buasbuas dengan konsentrasi yang berbeda-beda dapat menghambat pertumbuhan bakteri Staphylococcus aureus, kemudian data dianalisis menggunakan Analisis Varians Non Faktorial (ANAVA) menunjukkan bahwa nilai $F_{\text {hitung }}$ $(337,54)>F_{\text {tabel }} 0,05(2,77)$, maupun $F_{\text {tabel }} 0,01(4,25)$. Dengan konsentrasi maksimum ekstrak yang lebih efektif menghambat pertumbuhan bakteri Staphylococcus aureus adalah $90 \%$ dengan rata-rata zona hambat $11 \mathrm{~mm}$.
\end{abstract}

Kata kunci: Premna pubescens Blume, Staphylococcus aureus, Zona Hambat, Sumuran

\section{EFFECT OF LEAF EXTRACT OF BUASBUAS FOR Staphylococcus aureus GROWTH}

\begin{abstract}
Buasbuas (Premna pubescens Blume) is one of the medicinal plants in Indonesia. This plant is known to contain potentially antibacterial flavonoids. Staphylococcus aureus is one of the bacteria that can cause poisoning. This study aims to determine whether buasbuas leaf extract can inhibit the growth of Staphylococcus aureus bacteria and to obtain the data of excretion concentration of leaves of buasbuas yeng produce the largest inhibition zone. This research was conducted at Medan Health Laboratory using the method of wells. The buasbuas leaves have been extracted ethanol, diluted using aquadest with concentrations of $0 \%, 50 \%, 60 \%, 70 \%, 80 \%, 90 \%$ and dripped into MSA (Mannitol Salt Agar) medium which has been inoculated with bacteria and given a wellbore. After that it was incubated for $1 \times 24$ hours with temperature $37^{\circ} \mathrm{C}$. The result of this research showed that the provision of buasbuas leaf extract with different concentrations can inhibit the growth of Staphylococcus aureus bacteria, then the data analyzed by Non Factorial Variance Analysis (ANAVA) showed that Fcount $(337,54)>$ Ftabel $0,05(2,77)$, and Ftabel 0.01 (4.25). With the maximum concentration of extracts that more effectively inhibited the growth of Staphylococcus aureus bacteria was $90 \%$ with an average of $11 \mathrm{~mm}$ inhibit zone.
\end{abstract}

Keywords: Premna pubescens Blume. Staphylococcus aureus, Inhibitor zone, difusion

\section{Pendahuluan}

Salah satu tumbuhan obat yang ada di Indonesia ialah buasbuas (Premna pubescens Blume). Tumbuhan ini memiliki khasiat sebagai obat namun belum banyak masyarakat yang mengenal tanaman ini. Penelitian Adyttia, dkk. (2013) mendapatkan hasil bahwa pada ekstrak etanol 70\% dari daun buasbuas (Premna cordifolia) mengandung senyawa yang tergolong alkaloid, flavonoid, triterpenoid, fenol, tanin dan saponin. Hasil penelitian yang dilakukan oleh Majidah dkk (2014) ekstrak daun seledri yang mengandung flavonoid memiliki daya antibakteri terhadap pertumbuhan $S$. mutans dan konsentrasi terendah 
dari ekstrak daun seledri yang masih memiliki daya antibakteri adalah konsentrasi 12,5\%. Pulungan, A.S. 2017 juga mengemukakan bahwa terdapat kemampuan antijamur dari daun kunyit.

Penyakit akibat pangan (food borne diseases) yang terjadi segera setelah mengkonsumsi pangan, umumnya disebut dengan keracunan. Pangan dapat menjadi beracun karena telah terkontaminasi oleh bakteri patogen yang kemudian dapat tumbuh dan berkembangbiak selama penyimpanan, sehingga mampu memproduksi toksin yang dapat membahayakan manusia. Selain itu, ada juga makanan yang secara alami sudah bersifat racun seperti beberapa jamur atau tumbuhan dan hewan. Salah satu bakteri yang dapat menyebabkan keracunan adalah Staphylococcus aureus (Badan POM, 2008).

Penggunaan daun buasbuas sebagai alternatif antibakteri, karena pada daun buasbuas mengandung senyawa flavonoid. Berdasarkan penelitian yang dilakukan oleh Restuati, dkk. (2014) hasil uji fitokimia yang dilakukan telah di peroleh hasil bahwa metabolit sekunder dari ekstrak daun Premna pubescens positif mengandung alkaloid, steroid, flavonoid, saponin. Berdasarkan penelitian yang dilakukan oleh Darmawi, dkk. (2013) menemukan bahwa getah jarak cina yang mengandung flavonoid dapat menghambat pertumbuhan bakteri Staphylococcus aureus secara in vitro dengan konsentrasi yang paling optimal adalah 100\%. Kemudian hasil peneltian Hidayat, (2015), Martina Restuati (2016) menunjukkan bahwa ekstrak daun buasbuas dapat menghambat pertumbuhan bakteri Bacillus cereus pada konsentrasi $50 \%$.

Buasbuas adalah tumbuhan dengan habitus perdu yang habitatnya hidup di hutan dan pekarangan rumah dengan tinggi dapat mencapai 3-10 meter. Tumbuhan ini bercabang dengan memiliki bentuk daun panjang oval dan memiliki banyak anak daun. Tumbuhan ini memiliki bunga berwarna putih berbentuk kapsul sepanjang $1 \mathrm{~cm}$ dan lebarnya kira-kira $8 \mathrm{~cm}$ serta memiliki biji bulat yang banyak (Wahyuni dkk., 2014).

Tanaman buasbuas memproduksi senyawa metabolit yang digunakan sebagai alat pertahanan dari organisme pengganggu atau sebagai pelindung bagi tumbuhan tersebut dimana senyawa metabolit sekunder tersebut dapat juga dimanfaatkan manusia sebagai bahan obat-obatan karena adanya senyawa bioaktif. Daun tanaman ini dapat dikonsumsi dan berkhasiat sebagai obat. Daun buasbuas memiliki bau dan rasa yang khas sehingga diduga memiliki kandungan metabolit sekunder yang cukup tinggi (Mia dkk., 2014). Penelitian Adyttia, dkk. (2013) mendapatkan hasil bahwa pada ekstrak etanol $70 \%$ dari daun buasbuas mengandung senyawa yang tergolong alkaloid, flavonoid, steroid dan saponin.
Staphylococcus aureus adalah bakteri kokus sel gram positif yang tidak membentuk spora, tidak motil, berbentuk bulat, biasanya tersusun rangkaian tak beraturan seperti anggur. Ukuran dari bakteri ini adalah berdiameter 0,8 - $1 \mu$. Bakteri ini mudah tumbuh pada berbagai perbenihan dan mempunyai metabolisme aktif serta menghasilkan pigmen yang bervariasi dari putih sampai kuning tua. Beberapa di antaranya terdapat di kulit dan selaput mukosa manusia.

Intoksikasi bawaan pangan disebabkan oleh toksik dari Staphylococcus aureus. Intoksikasi ini sering terjadi di seluruh dunia. Enterotoksin yang dihasilkan oleh strain Staphylococcus aureus berkaitan dengan keracunan pangan. Bakteri Staphylococcus aureus dapat ditemukan di dalam hidung, tenggorokan, kulit, rambut dan bulu ternak termasuk unggas dan manusia. Bakteri ini juga dapat ditemukan menginfeksi kulit yang luka atau bengkak pada manusia dan ternak. Kontaminasi bakteri ini seara umum terjadi berasal dari sumber tersebut (Wardah, 2013).

\section{Bahan dan Metode}

Penelitian ini dilaksanakan di Laboratorium Kesehatan Medan dengan menggunakan metode sumuran. Daun buasbuas yang telah menjadi ekstrak etanol, diencerkan menggunakan aquadest dengan konsentrasi $0 \%$, $50 \%, 60 \%, 70 \%, 80 \%, 90 \%$ dan diteteskan ke dalam media MSA (Mannitol Salt Agar) yang telah diinokulasi bakteri serta diberi lubang sumuran. Setelah itu diinkubasi selama $1 \times 24$ jam dengan suhu $37^{\circ} \mathrm{C}$. Alat dan bahan yang digunakan yakni blender, rotary evaporator, timbangan, cawan petri, biakan bakteri Staphylococcus aureus, Ekstrak daun bausbuas, media MSA, etanol, aquadest.

\section{Hasil dan Pembahasan}

Berdasarkan penelitian yang telah dilakukan, diperoleh data yang menunjukkan bahwa ekstrak daun buasbuas (Premna pubescens Blume) yang menunjukkan zona hambat terbesar adalah pada konsentrasi ekstrak 90\%. Pemberian ekstrak daun buasbuas dengan konsentrasi yang berbeda-beda menyebabkan daerah/zona hambat yang bervariasi terhadap bakteri Staphylococcus aureus.

Diameter zona hambat yang terbentuk pada pemberian ekstrak daun buasbuas terhadap pertumbuhan bakteri Staphylococcus aureus tampak berbeda-beda pada tiap perlakuan. Dari tabel transformasi di atas, dapat dilihat diameter zona hambat yang terkecil adalah $0.707 \mathrm{~mm}$ pada konsentrasi ekstrak daun buasbuas 0\%., dan diameter zona hambat terbesar adalah 3,535 mm pada konsentrasi ekstrak 90\%. Untuk lebih jelasnya dapat diamati pada Grafik 1. di bawah ini: 


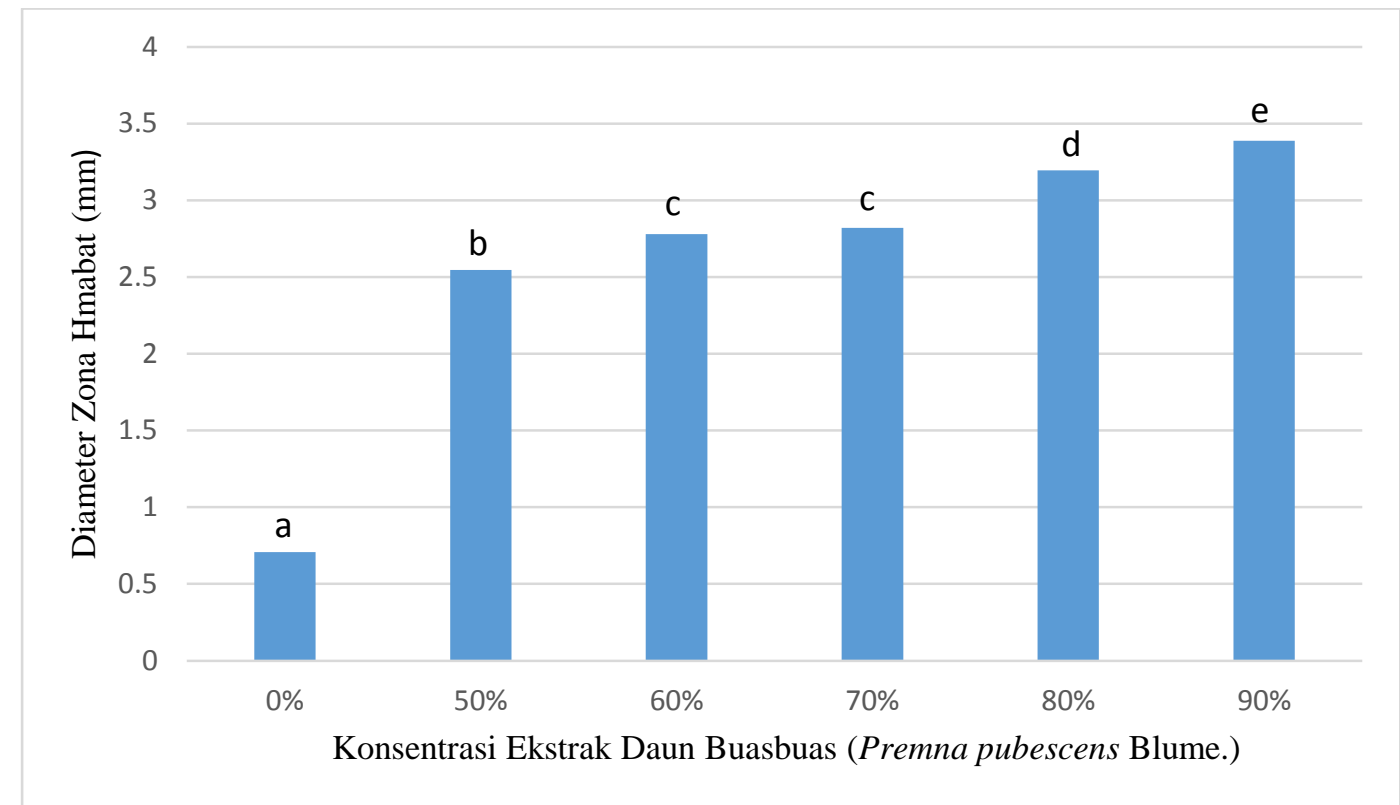

Gambar 1. Grafik Pengaruh Ekstrak Daun Buasbuas (Premna pubescens Blume.) Terhadap Zona Hambat/Diameter yang Terbentuk

Dari Grafik di atas terdapat notasi huruf yang berbeda-beda, huruf yang berbeda menunjukkan perbedaan yang nyata antara tiap konsentrasinya, sedangkan yang dinyatakan dengan huruf yang sama menunjukkan tidak adanya beda nyata. Dari grafik di atas terlihat antara konsetrasi 50\% dengan konsentrasi $60 \%$ memiliki notasi huruf yang sama, hal ini berarti antara perlakuan 50\% ekstrak daun buasbuas dengan konsentrasi 60\% ekstrak daun buasbuass tidak ada perbedaan yang nyata. Dan terlihat antara perlakuan $0 \%$ dengan $50 \%, 60 \%$, 70\%,
80\%, 90\% memiliki notasi huruf yang berbeda, hal ini berarti adanya beda nyata antara perlakuan $0 \%$ dengan 50\%, 60\%, 70\%, 80\%, 90\%.

Dari data di atas disusun Daftar Analisis Sidik Ragam untuk mengetahui apakah perlakuan tersebut menunjukan pengaruh yang nyata atau tidak terhadap parameter yang diamati. Analisis varian atau sidik ragam merupakan suatu cara untuk menguraikan ragam total menjadi komponen ragam. Dapat dilihat pada Tabel 1. di bawah ini:

Tabel 1. Daftar Analisis Sidik Ragam Pengaruh Ekstrak Daun Buasbuas (Premna pubescens Blume) Terhadap Pertumbuhan Bakteri Staphylococcus aureus

\begin{tabular}{|c|c|c|c|c|c|c|}
\hline $\begin{array}{c}\text { Sumber } \\
\text { Keragaman }\end{array}$ & $\begin{array}{c}\text { Derajat } \\
\text { Bebas } \\
\text { (DB) }\end{array}$ & $\begin{array}{c}\text { Jumlah } \\
\text { Kuadrat } \\
\text { (JK) }\end{array}$ & $\begin{array}{c}\text { Kuadrat } \\
\text { Tengah } \\
\text { (KT) }\end{array}$ & $\begin{array}{c}\text { F hitung } \\
\text { (Fh) }\end{array}$ & $\begin{array}{c}\text { F tabel } \\
0,05\end{array}$ & $\begin{array}{c}\text { F tabel } \\
0,01\end{array}$ \\
\hline Perlakuan & 5 & 18,566 & 3,713 & & & \\
\hline Galat & 18 & 0,207 & 0,011 & $337,54^{* *}$ & 2,77 & 4,25 \\
\hline Total & 23 & 18,773 & & & & \\
\hline
\end{tabular}

Keterangan $^{* *}=$ Beda Sangat Nyata

Berdasarkan hasil Analisis Sidik Ragam pada Tabel 4.3. dapat dilihat bahwa perlakuan pemberian ekstrak daun buasbuas memberikan pengaruh yang sangat nyata terhadap daerah hambatan bakteri Staphylococcus aureus. Nilai $F_{\text {hitung }}(337,54)$ dan nilai $F_{\text {tabel }} 0,05(2,77), F_{\text {tabel }} 0,01$ $(4,25)$, hal ini berarti nilai $F_{\text {hitung }}(337,54)>F_{\text {tabel }}$ $0,05(2,77)$, dan $F_{\text {tabel }} 0,01(4,25)$ dan menunjukkan bahwa beda sangat nyata, dimana Ho ditolak dan Ha diterima pada taraf kepercayaan 99\%.

Dari data yang diperoleh menunjukkan bahwa ekstrak daun buasbuas memiliki aktivitas antibakteri berdasarkan zona hambat yang dihasilkan. Terjadinya penghambatan terhadap pertumbuhan bakteri Staphylococcus aureus disebabkan oleh ekstrak daun buasbuas yang mengandung senyawa flavonoid yang bersifat 
sebagai antibakteri. Penggunaan daun buasbuas sebagai obat alami masih jarang digunakan oleh masyarakat. Dalam penelitian ini ekstrak daun buasbuas digunakan untuk menghambat pertumbuhan Staphylococcus aureus secara in vitro. Pemanfaatan tanaman obat sebagai bahan alternatif antimikroba biasanya menggunakan beberapa jenis flavonoid yang terkandung dalam tanaman, di dalam daun buasbuas mengandung senyawa flavonoid. Flavonoid merupakan golongan terbesar senyawa fenol. Mekanisme kerja senyawa flavonoid bekerja sebagai antibakteri dengan cara membentuk senyawa kompleks terhadap protein ekstraseluler yang mengganggu keutuhan membran sel bakteri. Mekanisme kerjanya dengan cara mendenaturasi protein sel bakteri dan merusak membran sel tanpa diperbaiki lagi (Haryati dkk., 2015).

Darmawi, dkk. (2013) menyatakan bahwa senyawa fenol mampu memutuskan ikatan peptidoglikan dalam usahanya menerobos dinding sel. Setelah menerobos dinding sel, senyawa fenol akan menyebabkan kebocoran nutrien sel dengan cara merusak ikatan hidrofobik komponen membran sel (seperti protein dan fospolipida) sehingga terjadinya kerusakan pada membran sel bakteri yang mengakibatkan terhambatnya aktivitas dan biosintesa enzim-enzim spesifik yang diperlukan dalam reaksi metabolisme bakteri.

Senyawa alkaloid bersifat antibakteri, diduga dengan mengganggu komponen penyusun peptidoglikan pada sel bakteri sehingga lapisan dinding sel tidak terbentuk secara utuh dan menyebabkan kematian sel.

Saponin akan mengganggu tegangan permukaan dinding sel, maka saat tegangan permukaan terganggu zat antibakteri akan dapat dengan mudah masuk kedalam sel dan akan mengganggu metabolisme hingga akhirnya terjadilah kematian bakteri. Saponin termasuk dalam zat antibakteri yang menghambat fungsi membran sel mikroba. Saponin membentuk senyawa kompleks dengan membran sel melalui ikatan hidrogen sehingga menghancurkan sifat permeabilitas dinding sel, menyebabkan pelepasan isi sel dan menimbulkan kematian sel (Permatasari dkk., 2013).

Steroid dapat menghambat pertumbuhan bakteri gram positif. Mekanisme kerja steroid dalam menghambat mikroba adalah dengan merusak membran plasma sel mikroba, sehingga menyebabkan bocornya sitoplasma keluar sel yang selanjutnya menyebabkan kematian sel. Diduga hal tersebut disebabkan karena molekul steroid memiliki gugus nonpolar (hidrofobik) dan polar (hidrofilik) sehingga memiliki efek surfaktan yang dapat melarutkan komponen fosfolipid membran plasma. Dan fosfolipid merupakan komponen dominan yang menyusun membran plasma sel mikroba (Haryati dkk., 2015).

Mekanisme dari masing-masing senyawa metabolit sekunder tersebut saling bersinergis sehingga menambah efektivitas dan aktivitas dari ekstrak daun buasbuas yang mengandung metabolit sekunder berupa flavonoid, alkaloid, saponin, dan steroid dalam menghambat pertumbuhan bakteri staphylococcus aureus secara in vitrro sehingga menyebabkan adanya zona hambat/daerah bening disekitar sumuran yang berisikan ekstrak daun buasbuas dengan berbagai konsentrasi.

\section{Kesimpulan}

Pemberian ekstrak daun buasbuas (Premna pubescens Blume) dapat menghambat pertumbuhan bakteri Staphylococcus aureus secara in vitro. Pada konsentrasi 50\%,60\%,70\%,80\% dan 90\% ekstrak daun buasbuas dapat menghambat pertumbuhan bakteri Staphylococcus aureus. Dimana daerah bening/zona hambat yang dihasilkan dari pemberian ektrak daun buasbuas (Premna pubescens Blume) terhadap pertumbuhan bakteri Staphylococcus aureus yang paling besar adalah $11 \mathrm{~mm}$ pada konsentrasi ekstrak daun buasbuas $90 \%$ sehingga respon hambatan ekstrak daun buasbuas sebagai antibakteri tergolong kuat.

\section{Daftar Pustaka}

Adyttia, A., Eka. K.U., Sri. W. 2013. Pengaruh Pemberian Ekstrak Etanol Daun BuasBuas (Premna Cordifolia. Linn) Terhadap Kadar Mda Tikus Wistar Jantan Pasca Paparan Asap Rokok. Jurnal Fitofarmaka Indonesia. 1(2): 35-42

Badan POM RI. 2008. Pengujian Mikrobiologi Pangan. ISSN 1829-9334. 9(2):1-12

Darmawi., Zakiah,H. M., Fahri,P. 2013. Daya Hambat Getah Jarak Cina Uatropha multifida L.) Terhadap Staphylococcus aureus Secara In Vitro. Jurnal Medika Veterinaria. 7(2):113-115

Haryati,N.,A., Chairul,S., Erwin. 2015. Uji Toksisitas dan Aktivitas Antibakteri Ekstrak Daun Merah Tanaman Pucuk Merah (Syzygium myrtifolium Walp.) Terhadap Bakteri Staphylococcus aureus dan Escherichia coli. Jurnal Kimia Mulawarman. 13(1):35-40

Hidayat, U. 2015. Pengaruh Ekstrak Daun BuasBuas (Premna pubescens Blume) Terhadap Pertumbuhan Bakteri Bacillus cereus Secara In Vitro. Skripsi. Universitas Negeri Medan : Medan.

Majidah, D., Fatmawati,D.W.A., Gunadi, A. 2014. Daya Antibakteri Ekstrak Daun Seledri (Apium graveolens L.) terhadap Pertumbuhan Streptococcus mutans sebagai Alternatif Obat Kumur. Artikel 
Ilmiah Hasil Penelitian Mahasiswa, Fakultas kedokteran, Universitas Jember : Jember.

Martina Restuati, Ulfa Hidayat, Ahmad Shafwan S. Pulungan, Nanda Pratiwi and Diky Setya Diningrat, 2016. Antibacterial Activity of Buasbuas (Premna pubescens Blume) Leaf Extracts against Bacillus cereus and Escherichia coli. Journal of Plant Sciences, 11: 81-85.

Mia, A.L., Mukarlina., Ari,H.Y. 2014. Uji Aktivitas Ekstrak Metanol dan n-Heksan Daun Buas-Buas (Premna serratifolia Linn.) pada Larva Nyamuk Demam Berdarah (Aedes aegypti Linn.). Jurnal Protobiont. 3(2):247- 251

Permatasari, G. A. A. A., Besung I. N. K. dan Mahatmi H. 2013. Daya Hambat Perasan Daun Sirsak terhadap Pertumbuhan Bakteri Escherichia coli. Indonesia Medicus Veterinus. 2 (2): 162 - 169
Pulungan, A.S.S., 2017. Aktivitas Antijamur Ekstrak Etanol Daun Kunyit (Curcuma longa LINN.) Terhadap Jamur Candida albicans. BIOLINK (Jurnal Biologi Lingkungan, Industri, Kesehatan), 3(2), pp.121-125.

Restuati, M.,Ilyas, S., Hutahaean,S.,Sipahutar, H. 2014. Study of The Extract Activities of Buasbuas Leaves (Premna pubescens) As Immunostimulant On Rats (Rattus novegicus).American Journal of BioScience. 2(6):244-250

Wahyuni, S., Mukarlina., Ari,H.Y. 2014. Aktivitas Antifungi Ekstrak Metanol Daun BuasBuas (Premna serratifolia) Terhadap Jamur Diplodia sp. pada Jeruk Siam (Citrus nobilis var. microcarpa). Jurnal Protobiont. 3(2):274 - 279

Wardah, S.T. 2013. Mikrobiologi Pangan. Andi Yogyakarta : Sidoarjo 